\title{
NON-WOVEN ION-EXCHANGE FIBROUS MATERIALS IN AIR SANITARY
}

\section{CLEANING}

\section{A. A.-A. Ennan ${ }^{1}$, R. M. Dlubovskii ${ }^{1}$, R. E. Khoma ${ }^{1,2^{*}}$}

${ }^{1}$ Physico-Chemical Institute of Environment and Human Protection, Preobrazhenskaya str., 3, Odessa 65082, Ukraine

${ }^{2}$ Odessa I.I. Mechnikov National University, Dvoryankaya str., 2, Odessa 65082, Ukraine *e-mail:rek@onu.edu.ua,eksvar@ukr.net

The review is devoted to non-woven sorption-filtering materials (NSFM) widely used equipment for gas cleaning from toxic gaseous and vaporous substances. The use of ion-exchange fibrous materials (IFM) as NSFM and the peculiarities of their preparation and structure have been analyzed. A lot of attention is paid to the mechanisms of chemisorption processes using IFM and to the role of water in their successful implementation. Individual options and some regularities of fibrous anionites, cationites, and polyampholytes interaction due to exchange reactions, neutralization, reduction-oxidation, complexation and precipitation with gaseous and vaporous substances are considered on specific examples.

Key words: ion-exchange fibers, chemisorption, toxic gases and vapors.

INTRODUCTION. Among the wide variety of adsorbents used in devices for sanitary purification of air from gaseous toxicants, a special place is occupied by nonwoven sorption-filtering materials (NSFM). Due to the short time to achieve sorption equilibrium in the case of NSFM, the rate of sorption of harmful components from gaseous media is several times higher than the rate of similar processes on granular adsorbents, which allows to purify air using thin layers of material. Due to the low resistance to air flow, such materials are used to equip gas cleaning equipment, including respirators - personal respiratory protective equipment (PRPE) from toxic gases [1-18].
FEATURES OF STRUCTURE, METHODS OF PRODUCTION AND APPLICATION OF NSFM IN GAS PURIFICATION. One of the kinds of NSFM is the so-called ion-exchange fibrous materials (IFM), the fibers of which are spatially crosslinked three-dimensional structures consisting of certain oriented macromolecules containing chemically active functional groups $[3,9,14,16]$. By their nature, IFMs are divided into cation-exchange resins (containing acid groups), anion-exchange resins (containing basic groups) and ampholytes (containing both acid and basic groups) [5-11, 14, $16,18]$. Now the main methods of obtaining ion-exchange chemisorption fibers are: 
- graft copolymerization of chemically active copolymer with finished fiber;

- polymeranalogical transformations in the finished fiber;

- formation of fibers from copolymers containing ionic groups.

For the synthesis of most ion-exchange fibrous materials are used: cellulose-viscose fiber (VF), polyacrylonitrile (PAN), polycaproamide (PCA) and polypropylene (PP) fibers, etc. [12-20].

In the post-Soviet space, the main producers of IFM are the Russian Federation and the Republic of Belarus [14, 18]. Abroad, little attention is paid to ion-exchange fibrous materials, except for China, where CATALON materials are produced [18] (similar in properties to the Belarusian PANION), and Japan - IONEX $[7,21]$. In addition, the United States [6], Japan [22, 23], South Korea [24], Iran [25], Uzbeki- $\operatorname{stan}[15,26]$, Ukraine $[1,3,4,8,9,12,27]$ and others, develop methods for producing IFMs, modifying them and study their physicochemical properties.

The modification of PAN fibers is carried out with ammonia, carbamide, phenylhydrazine, 1,1-dimethylhydrazine, mono-, di- and triethanolamines, $\mathrm{N}, \mathrm{N}$-dimethylethanolamine, diethylamine, triethylamine, ethylenediamine, hexamethylenediamine, diethylenetriamine, triethylenetetramine, aminoethylpiperazine and some other compounds, and fibrous chemisorbents containing $-\mathrm{NH}_{2},-\mathrm{NH}-$ and $-\mathrm{C}\left(\mathrm{NH}_{2}\right)=\mathrm{NH}$, functional groups and having high parameters of sorption capacity and chemical resistance are obtained [13-16, 26, $28,29]$.

Characteristics of the main brands of ion-exchange fibrous materials produced by industry are given in Table 1.

Table 1

Gas-absorbing IFMs manufactured in industrial batches.

\begin{tabular}{|c|c|c|c|c|c|}
\hline № & Chemical characteristic & $\begin{array}{l}\text { Trade } \\
\text { brand }\end{array}$ & $\begin{array}{l}\text { Functional } \\
\text { groups }\end{array}$ & $\begin{array}{l}\text { Static exchange } \\
\text { capacity, mg-eq/g }\end{array}$ & Reference \\
\hline 1 & 2 & 3 & 4 & 5 & 6 \\
\hline 1 & $\begin{array}{l}\text { Weakly acidic cation-exchan- } \\
\text { ger based on the hydrated and } \\
\text { saponified PAN fibers }\end{array}$ & $\begin{array}{l}\text { MION K-5 } \\
\text { FIBAN K-5 } \\
\text { PANION-110 } \\
\text { VION KN-1 }\end{array}$ & $-\mathrm{COOH}$ & $\begin{array}{l}3-7 \\
5-7^{* * *}\end{array}$ & $\begin{array}{l}{[30]} \\
{[14,19]} \\
{[30]} \\
{[7]}\end{array}$ \\
\hline 2 & $\begin{array}{l}\text { Weakly acidic cation-exchang- } \\
\text { er based on PP fibers and poly- } \\
\text { acrylic acid }\end{array}$ & FIBAN K-4 & $-\mathrm{COOH}$ & $5,0^{* * * x}$ & {$[14,16]$} \\
\hline 3 & $\begin{array}{l}\text { Strongly acidic cation-ex- } \\
\text { changer based on PAN fibers }\end{array}$ & $\begin{array}{l}\text { FIBAN K-1 } \\
\text { VION KS-2 }\end{array}$ & $-\mathrm{SO}_{3} \mathrm{H}$ & $\begin{array}{l}3,0^{*+*} \\
0,8-1,0^{*+* * *}\end{array}$ & $\begin{array}{l}{[14,16,} \\
19]\end{array}$ \\
\hline 4 & $\begin{array}{l}\text { Weakly basic anion-exchan- } \\
\text { ger. Copolymer of PAN fibers } \\
\text { and polymethylvinylpyridine } \\
\text { (PMVP) }\end{array}$ & VION AN-1 & & $2-2,5^{*}$ & {$[7,19,31]$} \\
\hline
\end{tabular}


Table 1

\begin{tabular}{lllll}
2 & 3 & 5 & 6 \\
\hline
\end{tabular}

Polyfunctional anion-exchan- VION AS-1

ger. Copolymer of PAN fib-

ers and PMVP alkylated with

epichlorohydrin (ECH)<smiles>Cc1ccccn1</smiles>

[7]

5

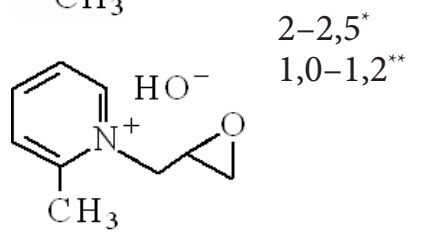

\begin{tabular}{|c|c|c|c|c|c|}
\hline 6 & $\begin{array}{l}\text { Weakly basic cellulose anion- } \\
\text { exchanger. Copolymer of VF } \\
\text { and PMVP }\end{array}$ & $\mathrm{CM}-\mathrm{A} 1$ & $\overbrace{\mathrm{CH}_{3}}^{\mathrm{N}}$ & до 3 & [4] \\
\hline \multirow[t]{2}{*}{8} & \multirow[t]{2}{*}{$\begin{array}{l}\text { Strongly basic anion-exchang- } \\
\text { er based on PAN fibers }\end{array}$} & \multirow[t]{2}{*}{ PANION-320 } & $-\left[\mathrm{N}\left(\mathrm{CH}_{3}\right)_{3}\right]^{+}$ & $1,5-2.5^{* *}$ & \multirow[t]{2}{*}{ [30] } \\
\hline & & & $-\mathrm{N}\left(\mathrm{CH}_{3}\right)_{2}$ & $0,8-1,5^{*}$ & \\
\hline 9 & $\begin{array}{l}\text { Strongly basic anion-exchang- } \\
\text { er based on PAN fibers }\end{array}$ & FIBAN A-1 & $-\mathrm{N}^{+}\left(\mathrm{CH}_{3}\right)_{3}$ & $2,5-3,2^{*}$ & {$[14,16]$} \\
\hline 10 & $\begin{array}{l}\text { Amphoteric ionite based on } \\
\text { PAN fibers }\end{array}$ & FIBAN A-5 & $\begin{array}{l}-\mathrm{N}\left(\mathrm{CH}_{3}\right)_{2} \\
=\mathrm{NH} \\
-\mathrm{COOH}\end{array}$ & $\begin{array}{l}4,2^{*} \\
0,5^{* * *}\end{array}$ & {$[14,16]$} \\
\hline 11 & $\begin{array}{l}\text { Strongly basic anion-exchanger } \\
\text { based on PAN fibers }\end{array}$ & FIBAN A-6 & $\begin{array}{l}\equiv \mathrm{N}^{+} \\
=\mathrm{NH}\end{array}$ & $\begin{array}{l}2,0^{*} \\
0,8^{*}\end{array}$ & {$[14,16]$} \\
\hline 12 & $\begin{array}{l}\text { Amphoteric ionite. Copolymer } \\
\text { of PAN fibers, methyl acrylate } \\
\text { and itaconic acid (followed by } \\
\text { treatment with polyamines) }\end{array}$ & PANION-220 & $\begin{array}{l}-\mathrm{COOH} \\
\equiv \mathrm{N}^{+} \\
=\mathrm{NH} \\
-\mathrm{NH}_{2}\end{array}$ & $\begin{array}{l}3,5-7,0^{* * *} \\
0,5-1,5^{*}\end{array}$ & {$[30]$} \\
\hline 13 & $\begin{array}{l}\text { Amphoteric ionite. Copolymer } \\
\text { of PAN fibers, methyl acrylate } \\
\text { and itaconic acid (followed by } \\
\text { treatment with polyamines) }\end{array}$ & $\begin{array}{l}\text { FIBAN AK-22 } \\
\text { PANION-210 } \\
\text { VION AN-3 }\end{array}$ & $\begin{array}{l}-\mathrm{COOH} \\
=\mathrm{NH} \\
-\mathrm{NH}_{2}\end{array}$ & $\begin{array}{l}3,5-7,0^{* * *} \\
1,0-3,0^{* * *} \\
0,5-1,5^{*} \\
1,5-7,0^{*}\end{array}$ & $\begin{array}{l}{[14,16]} \\
{[30]} \\
{[32]}\end{array}$ \\
\hline 14 & $\begin{array}{l}\text { Medium basic anion-exchanger } \\
\text { based on PAN fibers }\end{array}$ & PANION-310 & $\begin{array}{l}=\mathrm{NH} \\
-\mathrm{NH}\left(\mathrm{CH}_{3}\right)_{2}\end{array}$ & $4-5^{*}$ & {$[30]$} \\
\hline
\end{tabular}

$\overline{{ }^{*} \text { Static exchange capacity, measured relative to } 0.1 \mathrm{~N} \mathrm{HCl} ;{ }^{* \star} \text { Static exchange capacity measured relative to } 0.1 \mathrm{~N} \mathrm{NaCl}}$.

${ }^{* * *}$ Static exchange capacity, measured relative to $0.1 \mathrm{~N} \mathrm{NaOH}$ 
The most wide use of IFMs was in the manufacture of replaceable gas mask elements (RGME) for the equipment of lightweight PRPE. High speed and efficiency of air purification at insignificant aerodynamic resistance in combination with physical and mechanical structure of the IFM acceptable for "embed- ding" RGMEs in the respirator mask space of respirators allowed to create a light and comfortable gas-dust respirator type "Snowball" (with 3-4 times smaller weight and 2-2.5 times lower initial resistance to respiration compared to the standard cartridge respirator RU-60M) Table $2[3,9,33]$.

Light filtering gas and dust respirators equipped with IFM [33].

Table 2

\begin{tabular}{|c|c|c|}
\hline \multicolumn{2}{|c|}{$\begin{array}{l}\text { Name, type, class of respirator (compliance), } \\
\text { technical conditions for production }\end{array}$} & Protective function \\
\hline \multirow{5}{*}{$\begin{array}{l}\text { TU U 33.1-01530125- } \\
\quad 0252009\end{array}$} & $\begin{array}{l}\text { "Snowball” FMA1P2 } \\
\text { (DSTU EN 1827-2001) }\end{array}$ & $\begin{array}{l}\text { Vapors of organic compounds with a boiling } \\
\text { point above } 65^{\circ} \mathrm{C} \text {; aerodisperse particles }\end{array}$ \\
\hline & $\begin{array}{l}\text { “Snowball” FMB1P2 } \\
\text { (DSTU EN 1827-2001) }\end{array}$ & $\begin{array}{l}\text { Chlorine, hydrogen sulfide, hydrogen cyanide; } \\
\text { aerodisperse particles }\end{array}$ \\
\hline & $\begin{array}{l}\text { “Snowball” FME1P2 } \\
\text { (DSTU EN 1827-2001) }\end{array}$ & $\begin{array}{l}\text { Acid gases and acid vapors; aerodisperse parti- } \\
\text { cles }\end{array}$ \\
\hline & $\begin{array}{l}\text { "Snowball” FMK1P2 } \\
\text { (DSTU EN 1827-2001) }\end{array}$ & $\begin{array}{l}\text { Ammonia and vapors of nitrogen-containing } \\
\text { organic bases; aerodisperse particles }\end{array}$ \\
\hline & $\begin{array}{l}\text { “Snowball” FMГаз2P2(Ш) } \\
\text { (DSTU EN 1827-2001) }\end{array}$ & $\begin{array}{l}\text { Acid gases and acid vapors, ammonia and va- } \\
\text { pors of nitrogen-containing organic bases, } \\
\text { ozone, vapors of organic compounds; aerodis- } \\
\text { perse particles }\end{array}$ \\
\hline
\end{tabular}

IFMs are also used to equip gas treatment plants with a capacity of up to $100,000 \mathrm{~m}^{3} / \mathrm{h}$. for the capture of acidic $\left(\mathrm{SO}_{2}, \mathrm{HF}, \mathrm{SiF}_{4}, \mathrm{HCl}\right.$, $\left.\mathrm{Cl}_{2}, \mathrm{NO}_{2}\right)$ or basic $\left(\mathrm{NH}_{3}\right)$ gases, as well as mists of acids and other compounds; to make protective cavers, counteracting the ingress of toxicants released from the surface of electrolysis baths [30, 34], in submerged arc welding and the production of fused fluxes $[9,35]$, etc. In this case, the 90-98\% degree of purification of gases is reached. Gases with a toxic impurity content of 0.1 to $500 \mathrm{mg} / \mathrm{m}^{3}$ at a temperature of +1 to $+70{ }^{\circ} \mathrm{C}$ and a relative humidity of $30-$ $100 \%$ lend themselves to purification. The cost of purification of $1000 \mathrm{~m}^{3}$ of air from $\mathrm{SO}_{2}$ to
MPC is an order of magnitude lower compared to purification with granular sorbents $[5,36]$.

The use of IFMs for individual gas protection is not limited to the manufacture of RGME respirators. They are also used for the manufacture means of skin protection for workers employed in industries with particularly harmful working conditions: air and moisture-proof workwear with IFM is proof against toxic substances, and sufficient mechanical strength and chemical resistance formed their ability for multiple regeneration [6, 13-16, 18, 37-39].

CHEMISORPTION PROCESSES USING IFMS. IFMs, as a special type of chemical reagents, can enter into reactions of addition, de- 
composition or displacement, with the participation of ionic groups, with gases, vapors and liquid aerosols $[9,13,14,17,31,40]$. In this case, the processes of metabolism, neutralization, oxidation-reduction, complexation and precipitation are possible not only on the surface of the ionite fiber, but also in its entire volume. In most cases, the interaction product is chemically bound to the ionite. The absorption of gases is also partly due to their dissolution in water contained in the swellable ion-exchanger.

Stretching of the matrix during the swelling of the IFM in water vapor promotes the rapid penetration of sorbate gas molecules into the ion-exchanger phase and the exit of reaction products from it. Therefore, the presence of moisture in the system not only does not poison such sorbents (unlike activated carbon, zeolites, silicagels, etc.), but also promotes gas and vapor absorption. In some cases, water is one of the components involved in the gas absorption reaction. The high affinity of ion-exchangers for water can be successfully used for the efficient dehumidification of various gases and their mixtures. With the help of IFM it is possible to absorb gaseous and vaporous substances not only of acidic $\left(\mathrm{SO}_{2}, \mathrm{SO}_{3}, \mathrm{HCl}, \mathrm{HF}, \mathrm{Cl}_{2}, \mathrm{HNO}_{3}\right.$, $\left.\mathrm{H}_{2} \mathrm{SO}_{4}, \mathrm{H}_{2} \mathrm{~S}, \mathrm{CH}_{3} \mathrm{COOH}\right)$ or basic $\left(\mathrm{NH}_{3}\right.$, organic amines), but also neutral gases $\left(\mathrm{O}_{2}, \mathrm{Hg}\right)$, vapors and aerosols [2-17, 19, 32, 35-38, 41, 42].

Below, on specific examples of greatest interest for practice, some options and some patterns of interaction of IFM with gaseous systems of different nature are considered.

CHEMISORPTION OF ACID GASEOUS SUBSTANCES. The gases, vapors and aerosols with acid properties are the most numerous objects of chemisorption on IFMs. Their absorption in most cases is carried out by reac- tions of neutralization of the hydroxyl or carbonate form of strongly basic anion-exchange resins or formation of "ammonium" salts with primary, secondary or tertiary amino groups of weakly basic IFMs. The mechanisms of the processes that take place in this case are not the same for all chemisorbed substances and are sometimes quite complex.

SORPTION OF ANHYDRIDES OF OXYGEN-CONTAINING ACIDS. Of the gases that are anhydrides of oxygen-containing acids, oxides of sulfur (IV), carbon (IV) and nitrogen (IV), as well as mists of the corresponding acids are of most practical interests. Oxides of sulfur (IV) and carbon (IV) are effectively absorbed by hydroxyl $[2,11,13,14,41]$ and chloride [11] forms of strongly basic fibrous anion-exchangers. This process is greatly facilitated by the presence of water in the gas phase. At the beginning of the process the following reactions occur:

$$
\begin{aligned}
& 2\left[\mathrm{RR}^{\prime} \mathrm{R} " \mathrm{R} " \mathrm{~N}\right] \mathrm{OH}+\mathrm{SO}_{2} \rightarrow \\
& \rightarrow\left[\mathrm{RR}^{\prime} \mathrm{R}^{\prime \prime} \mathrm{R}^{\prime \prime} \mathrm{N}\right]_{2} \mathrm{SO}_{3}+\mathrm{H}_{2} \mathrm{O}, \\
& 2\left[\mathrm{RR}^{\prime} \mathrm{R}^{\prime \prime} \mathrm{R} " \mathrm{~N}\right] \mathrm{OH}+\mathrm{CO}_{2} \rightarrow \rightarrow \\
& \rightarrow\left[\mathrm{RR}^{\prime} \mathrm{R}^{\prime \prime} \mathrm{R}^{\prime \prime} \mathrm{N}\right]_{2} \mathrm{CO}_{3}+\mathrm{H}_{2} \mathrm{O},
\end{aligned}
$$

where $\mathrm{R}$ - the matrix of the anion-exchange resin; R', R" and R"' are a hydrocarbon radical or other radical.

The separated water causes the possibility of further absorption of gases due to the transition of the anion-exchange resin into the form of an acidic anion of the corresponding acid:

$$
\begin{aligned}
& \text { [RR'R"R"'N] }]_{2} \mathrm{SO}_{3}+\mathrm{H}_{2} \mathrm{O}+\mathrm{SO}_{2} \underset{\leftarrow}{\leftarrow} \\
& \underset{\leftarrow}{2}[\text { RR'R"R"'N]HSO, } \\
& \text { [RR'R"R"'N }]_{2} \mathrm{CO}_{3}+\mathrm{H}_{2} \mathrm{O}+\mathrm{SO}_{2} \underset{\leftarrow}{\leftarrow} \\
& \stackrel{\leftarrow}{\leftarrow 2}\left[\mathrm{RR}^{\prime} \mathrm{R} \text { "R"'N] } \mathrm{HCO}_{3}\right. \text {. }
\end{aligned}
$$


The reactions of the above type are reversible. When heated, the middle form is formed again with the release of water and the corresponding anhydride. It should be noted that the thermal removal of chemisorbed sulfur (IV) oxide from anion-exchangers is not always possible due to the fact that in the phase of strongly basic anion-exchangers, absorbed $\mathrm{SO}_{2}$ is extremely rapidly oxidized by oxygen of the purified air stream $[13,43]$.

It is also possible to absorb sulfur (IV) oxide by the carbonate or hydrocarbonate form of strongly basic anion-exchangers by reaction (5) with subsequent binding of $\mathrm{SO}_{2}$ by reaction (4) $[2,13,43]$ :

$$
\begin{aligned}
{\left[R^{\prime}{ }^{\prime}{ }^{\prime} R " N\right]_{2} } & \mathrm{CO}_{3}+\mathrm{SO}_{2} \rightarrow \\
& \rightarrow\left[\mathrm{RR}^{\prime} \mathrm{R}^{\prime} \mathrm{R}{ }^{\prime \prime} \mathrm{N}\right]_{2} \mathrm{SO}_{3}+\mathrm{CO}_{2}
\end{aligned}
$$

According to reactions similar to those discussed above, the absorption of mists of sulfuric and other acids with strongly basic anion-exchangers is carried out $[2,3,9]$ :

$$
\begin{aligned}
& 2\left[\mathrm{RR}^{\prime} \mathrm{R} " \mathrm{R} \text { "'N]OH }+\mathrm{H}_{2} \mathrm{SO}_{4} \rightarrow\right. \\
& \rightarrow\left[\mathrm{RR}^{\prime} \mathrm{R}^{\prime} \mathrm{R} " \mathrm{~N}\right]_{2} \mathrm{SO}_{4}+2 \mathrm{H}_{2} \mathrm{O} \text {, } \\
& {\left[R R^{\prime}{ }^{\prime} \mathrm{R}^{\prime \prime} \mathrm{N}\right]_{2} \mathrm{SO}_{4}+\mathrm{H}_{2} \mathrm{SO}_{4} \rightarrow} \\
& \rightarrow 2\left[\mathrm{RR} \mathrm{R}^{\prime \mathrm{R}}{ }^{\prime} \mathrm{N}\right] \mathrm{HSO}_{4} \text {. } \\
& \text { RR'R"N }+\mathrm{nH}_{2} \mathrm{O} \stackrel{\leftarrow}{\leftarrow}\left[\mathrm{RR}^{\prime} \mathrm{R}^{\prime} \mathrm{NH}\right]^{+}+ \\
& +\mathrm{OH}^{-}+(\mathrm{n}-1) \mathrm{H}_{2} \mathrm{O} \text {, } \\
& (\mathrm{n}-1) \mathrm{H}_{2} \mathrm{O}+\mathrm{SO}_{2} \rightarrow \mathrm{SO}_{2} \cdot \mathrm{H}_{2} \mathrm{O}+(\mathrm{n}-2) \mathrm{H}_{2} \mathrm{O} \text {, } \\
& (\mathrm{n}-2) \mathrm{H}_{2} \mathrm{O}+2\left[\mathrm{RR}^{\prime} \mathrm{R}^{\prime} \mathrm{NH}\right]^{+}+2 \mathrm{OH}^{-}+ \\
& +\mathrm{SO}_{2} \cdot \mathrm{H}_{2} \mathrm{O} \rightarrow\left[\mathrm{RR}^{\prime} \mathrm{R}^{\prime} \mathrm{NH}\right]_{2} \mathrm{SO}_{3}+\mathrm{nH}_{2} \mathrm{O} \text {, } \\
& {[\text { RR'R”NH }]_{2} \mathrm{SO}_{3}+\mathrm{SO}_{2} \cdot \mathrm{H}_{2} \mathrm{O} \stackrel{\mathrm{nH}_{2} \mathrm{O}}{\longrightarrow}} \\
& \stackrel{\mathrm{nH}_{2} \mathrm{O}}{\longrightarrow} 2\left[\mathrm{RR}^{\prime} \mathrm{R} \text { NH] } \mathrm{HSO}_{3}\right. \text {, }
\end{aligned}
$$

$$
\begin{aligned}
2\left[\mathrm{RR}^{\prime} \mathrm{R} " \mathrm{NH}\right] \mathrm{HSO}_{3} \leftarrow\left[\mathrm{RR}^{\prime} \mathrm{R}^{\prime} \mathrm{NH}\right]_{2} \mathrm{~S}_{2} \mathrm{O}_{5}+ \\
+\mathrm{nH}_{2} \mathrm{O} .
\end{aligned}
$$

As follows from equations (1), (3), (8) (12), water is not only a reaction medium in which mass transfer and chemisorption processes take place, but also an essential participant in these processes, which is confirmed by data [45]. We found something similar in the study of $\mathrm{SO}_{2}$ capture by impregnated fibrous chemisorbents (IFCS) under static and dynamic conditions [46, 47].

For granular macroporous anion-exchangers with different functional groups, the chemisorption capacity of sulfur (IV) oxide varies in the following sequence:

$$
\begin{aligned}
\mathrm{RNH}\left(\mathrm{CH}_{2}\right)_{2} \mathrm{NH}_{2} & >\mathrm{RNH}\left(\mathrm{CH}_{2}\right)_{6} \mathrm{NH}_{2}> \\
& >\mathrm{RNH}\left(\mathrm{CH}_{2}\right)_{2} \mathrm{OH}>\mathrm{RNH}_{2},
\end{aligned}
$$

which the author of [48] attributes to the basicity of functional groups. In this case, the thermal regeneration of the anion-exchange resin $\mathrm{RNH}\left(\mathrm{CH}_{2}\right)_{2} \mathrm{NH}_{2}$ is difficult, and in the case of $\mathrm{RNH}\left(\mathrm{CH}_{2}\right)_{2} \mathrm{OH}$, a weaker bond is formed under interacting with $\mathrm{SO}_{2}$, which provides ease of thermal regeneration for practice. In our opinion, this is due to the formation of sulfite compounds by the interaction of $\mathrm{SO}_{2}$ with an anion-exchanger based on monoethanolamine (MEA), while for anion-exchange resin based on ethylenediamine (EDA) thermally and hydrolytically stable sulfates are formed $[44,49]$.

EDA-based fibrous anion-exchange resin has a lower sorption capacity for $\mathrm{SO}_{2}$ compared to N,N-dimethylpropylenediamine (DMPDA)based anion-exchange resin $[29,50]$, although EDA $\left(\mathrm{pK}_{\mathrm{a} 1}=7.49 ; \mathrm{pK}_{\mathrm{a} 2}=10.17\right.$ [51]) is more basic than DMPDA $\left(\mathrm{pK}_{\mathrm{a} 1}=7.67 ; \mathrm{pK}_{\mathrm{a} 2}=9.91\right.$ $[52])$. The authors of $[29,50]$ based only on 
quantum chemical calculations conclude that the processes of $\mathrm{SO}_{2} \cdot \mathrm{nH}_{2} \mathrm{O}$ ionization and sulfoxidation on the surface of PAN-EDA fibers are unlikely. This contradicts the experimental data from the study of interaction products in the systems $\mathrm{SO}_{2}-\mathrm{Am}-\mathrm{H}_{2} \mathrm{O}$ and $\mathrm{SO}_{2}-\mathrm{Am}-$ $\mathrm{H}_{2} \mathrm{O}-\mathrm{O}_{2}[44,49]$. In addition, nothing is said about the effect of the PAN matrix on the chemisorption of sulfur (IV) oxide by fibrous anion-exchangers $[29,50]$. Obviously, the participation of the primary and secondary amino groups of EDA in the formation of strong $\mathrm{N}-\mathrm{H} \bullet . . \mathrm{O}=\mathrm{C}$ hydrogen bonds creates a steric hindrance to their further protonation, which contributes to the above $[29,50]$.

The sorption capacity and the efficiency of absorption of sulfur (IV) oxide from the air are impacted by several factors of different directions [32]. With increasing content of quaternary amino groups, i.e. with increasing basicity of functional groups, anion-exchange resins containing tertiary amino groups are able to operate in the lower range of relative humidity of the gas stream. At the same time, the low dynamic capacity of strongly basic fibrous anion-exchangers limits the possibility of their use in fine air filters, where periodic regeneration of sorbents during operation is not provided. The absorption of $\mathrm{SO}_{2}$ from the air is carried out in the presence of two or more water molecules near the amino group of the anion-exchanger. Moreover, for each ion-exchanger there is an optimal range of relative air humidity, within which its dynamic activity for sulfur oxide is a maximum.

As the content of cation-exchange groups in the ion-exchanger increases, the sorption efficiency of $\mathrm{SO}_{2}$ decreases, and for polyampholites, the sorption capacity may not be realized at all. The sorption capacity of anion-exchange resins with tertiary groups increases both with an increase in their total anion-exchange capacity and with a change in the nature of functional groups, in particular, with the presence of additional secondary amino groups in their composition.

Nitrogen oxides are also almost completely absorbed by the hydroxyl form of strongly basic anion-exchangers via the stage of their dissolution in water $[9,11,13,40,53]$ :

$$
\begin{gathered}
2 \mathrm{NO}_{2}+\mathrm{H}_{2} \mathrm{O} \rightarrow \mathrm{HNO}_{3}+\mathrm{HNO}_{2}, \\
\mathrm{NO}_{2}+\mathrm{NO}+\mathrm{H}_{2} \mathrm{O} \rightarrow 2 \mathrm{HNO}_{2} .
\end{gathered}
$$

The formed nitric or nitrous acids are absorbed by a strongly basic anion-exchanger by neutralization reactions:

$$
\begin{aligned}
& \text { [RR'R" R"'N]OH }+\mathrm{HNO}_{3} \rightarrow \\
& \rightarrow\left[\mathrm{RR}^{\prime} \mathrm{R}^{\prime} \mathrm{R}^{\prime \prime} \mathrm{N}\right] \mathrm{NO}_{3}+\mathrm{H}_{2} \mathrm{O} \text {, } \\
& \text { [RR'R"R"'N]OH }+\mathrm{HNO}_{2} \rightarrow \\
& \rightarrow\left[\mathrm{RR}^{\prime} \mathrm{R}^{\prime} \mathrm{R} \text { "'N }\right] \mathrm{NO}_{2}+\mathrm{H}_{2} \mathrm{O} \text {. }
\end{aligned}
$$

The good kinetics characteristics of strongly basic anion-exchangers cause a fairly rapid course of the process with nitrous acid having no time to decompose by the reaction:

$$
3 \mathrm{HNO}_{2} \rightarrow \mathrm{HNO}_{3}+2 \mathrm{NO}+\mathrm{H}_{2} \mathrm{O} \text {. }
$$

The above reaction partially occurs when using weakly basic anion-exchangers due to the relatively low rates of their neutralization. This is evidenced by the presence in the gas leaving the filter with an anion-exchanger, of one mole of nitric(II) oxide for every three moles of $\mathrm{NO}_{2}$.

In addition to strongly basic and weakly basic anion-exchangers, weakly acidic cation-exchange resins in salt form and polyampholites can be used for the absorption of acid gases [9, $14,40]$. For example, oxides of carbon (IV) and 
sulfur (IV) in the presence of moisture can be absorbed by the sodium or ammonium form of carboxyl cation-exchange resin according to the schemes:

$$
\begin{aligned}
& \mathrm{R}-\mathrm{COONa}+\mathrm{CO}_{2}+\mathrm{H}_{2} \mathrm{O} \underset{\leftarrow}{\rightleftarrows}
\end{aligned}
$$

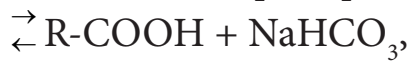

$$
\begin{aligned}
& \mathrm{R}-\mathrm{COONH}_{4}+\mathrm{SO}_{2}+\mathrm{H}_{2} \mathrm{O} \rightleftarrows \\
& \rightleftarrows \mathrm{R}-\mathrm{COOH}+\mathrm{NH}_{4} \mathrm{HSO}_{3} \text {. }
\end{aligned}
$$

SORPTION OF HYDROGEN HALIDES. Fibrous anion-exchangers very efficiently absorb mists of hydrohalic acids by neutralizing the latter with hydroxyl, carbonate or hydrocarbonate forms of strongly basic anion-exchangers (reactions 20-23) and primary, secondary or tertiary amino groups of weakly basic anionites (reaction 24) [3, 4, 7, 13, 54-56]. The absorption process largely depends on the presence of moisture in the system, as water is a direct participant in the interaction of $\mathrm{HCl}$ with the functional groups of fibrous anion-exchange resins $[13,56]$. When absorbing hydrogen chloride, the following reactions occur:

$$
\begin{aligned}
& \text { [RR'R" R"'N] OH + } \mathrm{HCl} \stackrel{\mathrm{nH}_{2} \mathrm{O}}{\longrightarrow} \\
& \stackrel{\mathrm{nH}_{2} \mathrm{O}}{\longrightarrow}\left[\mathrm{RR}^{\prime} \mathrm{R}^{\prime \prime} \mathrm{R} \text { "N] } \mathrm{Cl}+\mathrm{H}_{2} \mathrm{O}\right. \text {; } \\
& {\left[\mathrm{RR}^{\prime} \mathrm{R}^{\prime \prime} \mathrm{R} \text { "'N }\right]_{2} \mathrm{CO}_{3}+2 \mathrm{HCl} \stackrel{\mathrm{nH}_{2} \mathrm{O}}{\longrightarrow}} \\
& \stackrel{\mathrm{nH}_{2} \mathrm{O}}{\longrightarrow} 2 \text { [RR'R" R"'NH]Cl+ } \\
& +\mathrm{H}_{2} \mathrm{O}+\mathrm{CO}_{2} \text {; } \\
& \text { [RR'R" R"'N] } \mathrm{HCO}_{3}+\mathrm{HCl} \stackrel{\mathrm{nH}_{2} \mathrm{O}}{\longrightarrow} \\
& \stackrel{\mathrm{nH}_{2} \mathrm{O}}{\longrightarrow}\left[\mathrm{RR}^{\prime} \mathrm{R}\right. \text { "R"NH]Cl } \\
& +\mathrm{H}_{2} \mathrm{O}+\mathrm{CO}_{2} \text {; } \\
& \text { RR'R"N + HCl } \stackrel{\mathrm{nH}_{2} \mathrm{O}}{\longrightarrow} \\
& \stackrel{\mathrm{nH}_{2} \mathrm{O}}{\longrightarrow}\left[\mathrm{RR}^{\prime} \mathrm{R}^{\prime} \mathrm{NH}\right] \mathrm{Cl} \text {. } \\
& \text { [RR'R"NH]Cl}+n \mathrm{HCl} \stackrel{\mathrm{nH}_{2} \mathrm{O}}{\longrightarrow} \\
& \stackrel{\mathrm{nH}_{2} \mathrm{O}}{\longrightarrow}\left[\mathrm{RR}^{\prime} \mathrm{R}^{\prime} \mathrm{NH}\right] \mathrm{Cl} \cdot n \mathrm{HCl} \text {. }
\end{aligned}
$$

Processes (20) - (24) correspond to the stoichiometric addition of $\mathrm{HCl}$ to the main functional groups of ionite by the neutralization reaction. The amount of $\mathrm{HCl}$ absorbed by this mechanism may be less than or equal to the exchange capacity of the ion-exchanger; it depends on the basicity of the ionite, the concentration of $\mathrm{HCl}$ in the air and relative humidity $[13,56]$. $\mathrm{HCl}$ sorbed by equation (25) can be defined as "overequivalent". However, a clear distinction can be made between equivalent and overequivalent $\mathrm{HCl}$ only for strongly basic groups.

The mechanism of sorption of hydrogen fluoride by strongly basic anion-exchangers with nitrogen of the quaternary ammonium base can be described in the following stages [54, 55, 57-59]:

1. Dissolution of HF in water in the anionexchanger phase:

$$
\mathrm{HF}_{\text {gas }} \stackrel{\mathrm{H}_{2} \mathrm{O}}{\leftarrow} \mathrm{HF}_{\text {sol }}
$$

2. Dissociation and aquacomplexation of HF in solution:

$$
\begin{gathered}
\mathrm{HF}_{\text {sol }} \stackrel{\rightleftarrows}{\leftarrow} \mathrm{H}^{+}+\mathrm{F}^{-} ; \\
\mathrm{HF}_{\text {sol }}+\mathrm{H}^{+}+\mathrm{F}^{-} \stackrel{\mathrm{HF}}{\overline{2}}+\mathrm{H}^{+} .
\end{gathered}
$$

3. Exchange sorption of fluoride-difluoride ions by anion-exchange resin in $\mathrm{OH}$ form:

[RR'R"R'”N]OH + $\mathrm{HF} \stackrel{\rightleftarrows}{\leftarrow}$

$$
\stackrel{\rightleftarrows}{\leftarrow}\left[\mathrm{RR}^{\prime} \mathrm{R} \text { "R"'N]F + } \mathrm{H}_{2} \mathrm{O}\right. \text {; }
$$

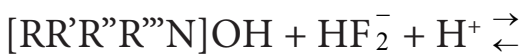

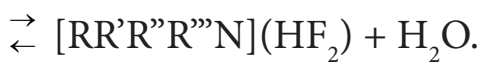

4. Sorption of additional HF due to complexation with nitrogen of the quaternary ammonium base or the formation of solvate shells around exchange sorbed $\mathrm{HF}_{2}^{-}$: 


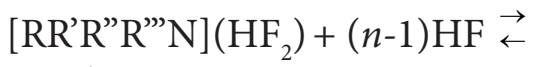

$\stackrel{\leftarrow}{\rightarrow}\left[\mathrm{RR}^{\prime} \mathrm{R}^{\prime} \mathrm{R}{ }^{\prime \prime} \mathrm{N}\right]\left[\mathrm{F}(\mathrm{HF})_{\mathrm{n}}\right]$, were $n=1-3$.

On the example of a weakly basic anion-exchange resin, it was found that the total amount of absorbed HF consists of exchangeand non-exchange-sorbed hydrogen fluoride. The amount of HF sorbed by the ionite by the reaction:

$$
\mathrm{R}-\mathrm{NH}_{2}+\mathrm{HF} \rightarrow\left[\mathrm{R}_{-} \mathrm{NH}_{3}^{+}\right] \mathrm{F}^{-},
$$

practically does not depend on its concentration in the gas-air mixture (AM) and is $0.7-0.8 \mathrm{mmol} / \mathrm{g}$. In addition, there is an invariant (equivalent) absorption of HF:

$$
\left[\mathrm{R}^{-N_{3}}\right]_{3}^{+} \mathrm{F}^{-}+i \mathrm{HF} \rightarrow\left[\mathrm{R}_{-} \mathrm{NH}_{3}^{+}\right]\left[\mathrm{F}(\mathrm{HF})_{\mathrm{i}}^{-}\right],
$$

where $i=1,2,3$.

The amount of non-exchange HF is proportional to its concentration in the GAM and is $1.3-3.5 \mathrm{mmol} / \mathrm{g}$. Such absorption of $\mathrm{HF}$ is associated with the possibility of solvation of amino groups and counterions of ion-exchanger by HF molecules $[57,58]$. This displaces water molecules and resolvates the functional groups, so that there is an osmotic swelling of the ionite in HF as in a highly polar solvent. The amount of moisture in the GAM is markedly manifested only at very low values of relative humidity $(<10 \%)$, which is also due to the high solvating ability of HF. Like water, exchange- and non-exchanged sorbed hydrogen fluoride in this case plays the role of a diffusion medium.

However, on $\mathrm{HF}-\mathrm{Am}-\mathrm{H}_{2} \mathrm{O}$ model systems, the authors of [60] showed that the interaction with highly basic amines $\left(\mathrm{pK}_{\mathrm{a}}>8\right)$ takes place mainly by the Bransted type with complete neutralization of hydrogen fluo- ride and formation of monohydrofluorides $[\mathrm{AmH}]^{+} \mathrm{F}^{-}$as end products, which corresponds to reactions (29) and (32); interaction with medium-strength monoamines $\left(\mathrm{pK}_{\mathrm{a}}<7\right)$ at concentrations exceeding the stoichiometric ratios of the reacting components relative to HF is accompanied by the formation of polyhydrofluorides of the total composition $[\mathrm{AmH}]^{+}\left[\mathrm{H}_{\mathrm{k} 1} \mathrm{~F}_{\mathrm{k}}\right]^{-}$, similar to reactions (30), (31) and (33).

Obviously, the difference in the behavior of strongly basic anion-exchangers [2] from highly basic monoamines [60] is due to the matrix effect of ion-exchange materials. The possibility of using carboxyl fibrous cationites for the sorption of hydrogen fluoride is based on the splitting reactions of salt forms of these cations as salts of weak acids $\left(\mathrm{pK}_{\mathrm{a}} \sim 6\right)$ by stronger acids formed by dissolving gases in "swelling" water [40]:

$$
\mathrm{R}-\mathrm{COONa}+\mathrm{HF} \stackrel{\mathrm{nH}_{2} \mathrm{O}}{\longrightarrow} \mathrm{R}-\mathrm{COOH}+\mathrm{NaF} \text {. }
$$

As can be seen from equation (29), when $\mathrm{HF}$ is captured by cationtes in the Na-form, salts of the corresponding acids are formed and accumulate in the ion-exchanger phase and ultimately in the interfiber space of RGMEs with IFMs. To prevent their entrainment and entry into the respiratory system, it is necessary to shield the RGME with a layer of dust-collecting material, which leads to an increase in material and labor intensity, deterioration of economic and ergonomic characteristics of products.

The latter occurs due to increased respiratory resistance of PRPE. In the case of HF, the situation is not changed even by the fact that during the formation of $\mathrm{NaF}$, the time of protective action of RGME increases due to the interaction of $\mathrm{NaF}$ and $\mathrm{HF}$ with the formation of $\mathrm{NaHF}_{2}$ hydrofluoride. Therefore, the use 
of cation-exchangers for the sorption of acid gases, including $\mathrm{HF}$, is undesirable.

SORPTION OF SILICON TETRAFLUORIDE. In case of sorption of $\mathrm{SiF}_{4}$ with strongly basic fibrous anionites, the following mechanism can be proposed $[2,13,35,59,61]$ :

1. Dissolution of $\mathrm{SiF}_{4}$, hydrolysis and complexation in the moisture of anion-exchanger according to the equation:

$$
\begin{gathered}
5 \mathrm{SiF}_{4}+(\mathrm{m}+6) \mathrm{H}_{2} \mathrm{O} \rightarrow \mathrm{H}_{2} \mathrm{SiF}_{6}+ \\
+2 \mathrm{H}\left[\mathrm{SiF}_{5} \cdot \mathrm{H}_{2} \mathrm{O}\right]+\mathrm{SiF}_{4} \cdot 2 \mathrm{H}_{2} \mathrm{O}+\mathrm{SiO}_{2} \cdot \mathrm{mH}_{2} \mathrm{O} \\
\mathrm{H}_{2} \mathrm{SiF}_{6} \stackrel{\mathrm{nH}_{2} \mathrm{O}}{\longrightarrow} 2 \mathrm{H}^{+}+\mathrm{SiF}_{6}^{2-}
\end{gathered}
$$

2. Exchange sorption of $\mathrm{SiF}_{6}^{2-}$ and $\mathrm{SiF}_{5} \cdot \mathrm{H}_{2} \mathrm{O}^{-}$ - by ionite in the hydroxyl form:

$$
\begin{aligned}
2\left[\mathrm{RR}^{\prime} \mathrm{R}^{\prime} \mathrm{R}\right. & \text { "N }] \mathrm{OH}+2 \mathrm{H}^{+}+\mathrm{Si} \mathrm{F}_{6}^{2-} \rightarrow \\
& \rightarrow\left[\mathrm{RR}^{\prime} \mathrm{R}^{\prime \prime} \mathrm{R}^{\prime \prime} \mathrm{N}\right]_{2}\left(\mathrm{SiF}_{6}\right)+2 \mathrm{H}_{2} \mathrm{O},
\end{aligned}
$$

$\left[\mathrm{RR}^{\prime} \mathrm{R}^{\prime} \mathrm{R} " \mathrm{~N}\right] \mathrm{OH}+\mathrm{H}^{+}+\mathrm{SiF}_{5} \cdot \mathrm{H}_{2} \mathrm{O}^{-} \rightarrow$

$$
\rightarrow\left[\mathrm{RR}^{\prime} \mathrm{R}^{\prime R} \mathrm{R} \text { "N }\right]\left(\mathrm{SiF}_{5}\right)+2 \mathrm{H}_{2} \mathrm{O} \text {. }
$$

In addition, the processes of hydrolytic decomposition of hexafluorosilicate anions in the anion-exchange phase should not be neglected $[35,62]$. Dried IFM practically does not sorb $\mathrm{SiF}_{4}$ from dehydrated GAM [59]. When sorbing $\mathrm{SiF}_{4}$ with weakly basic fibrous anion-exchange resins $[2,59,61]$, the following mechanism can be proposed, which includes reactions (35), (36) and the following stage:

$$
\begin{aligned}
2\left[\mathrm{RR}^{\prime} \mathrm{R}^{\prime} \mathrm{NH}\right]^{+} & +\underset{\mathrm{ni}_{2} \mathrm{O}}{\mathrm{SiF}_{2-}^{2-} \stackrel{\mathrm{nH}_{2} \mathrm{O}}{\longrightarrow}}\left[\mathrm{RR}^{\prime} \mathrm{R}^{\prime} \mathrm{NH}\right]_{2} \mathrm{SiF}_{6} ;
\end{aligned}
$$

SORPTION OF HYDROCYANIC ACID. With strongly basic anion-exchange resins in the $\mathrm{OH}$ form, hydrocyanic acid vapors interact by the usual neutralization reaction $[40,63]$ :

$$
\begin{aligned}
& \text { [RR'R"R"'N]OH + HCN } \rightarrow \\
& \rightarrow\left[\mathrm{RR}^{\prime} \mathrm{R}^{\prime} \mathrm{R} " \mathrm{~N}\right] \mathrm{CN}+\mathrm{H}_{2} \mathrm{O} \text {. }
\end{aligned}
$$

In the case of weakly basic anion-exchangers, the process is accompanied by the hydrolysis of the cyanide form with the formation of oxyamine:

$$
\text { RR'R”N + HCN } \rightarrow \text { [RR'R”N]CNH, }
$$

$\left[\mathrm{RR}^{\prime} \mathrm{R}^{\prime} \mathrm{N}\right] \mathrm{CNH}+\mathrm{H}_{2} \mathrm{O} \rightarrow$

$$
\rightarrow \text { RR'R"N-C(O) } \mathrm{NH}_{2} \text {. }
$$

SORPTION OF HYDROGEN SULFIDE. The sorption of hydrogen sulfide on anion-exchange resins in the $\mathrm{OH}$-form follows the mechanism of the usual neutralization reaction [17]. The sulfide form thus formed can additionally absorb an equimolar amount of $\mathrm{H}_{2} \mathrm{~S}[40,64]$ :

$$
\begin{aligned}
2\left[R^{\prime} R " R "\right. & \mathrm{N}] \mathrm{OH}+\mathrm{H}_{2} \mathrm{~S} \rightarrow \\
& \rightarrow\left[\mathrm{RR}^{\prime} \mathrm{R}^{\prime} \mathrm{R} " \mathrm{~N}\right]_{2} \mathrm{~S}+2 \mathrm{H}_{2} \mathrm{O},
\end{aligned}
$$

$[R R \text { 'R"R" N }]_{2} \mathrm{~S}+\mathrm{H}_{2} \mathrm{~S} \rightarrow$

$$
\rightarrow 2[R R \text { 'R"R"'N](HS). }
$$

Weakly basic anion-exchangers under dynamic conditions practically do not absorb hydrogen sulfide, because its aqueous solution is a too weak acid $\left(\mathrm{pK}_{\mathrm{a} 1}=7.02, \mathrm{pK}_{\mathrm{a} 2}=12.20 \div 15.00\right.$ at $25{ }^{\circ} \mathrm{C}$ [65]), so only strongly basic anion-exchangers are used. Hydrogen sulfide also be sorbed with strongly basic and weakly basic cation-exchangers in salt form with $3 \mathrm{~d}$ metals (for example, $\mathrm{Cu}^{2+}, \mathrm{Ni}^{2+}, \mathrm{Co}^{2+}, \mathrm{Cd}^{2+}, \mathrm{Zn}^{2+}$ ) [66], forming with it sparingly soluble sulfides, firmly held by the spatial matrix of chemisorbent:

$$
\begin{aligned}
{[\mathrm{R}-\mathrm{COO}]_{2} \mathrm{Me}+} & \mathrm{H}_{2} \mathrm{~S} \rightarrow \\
& \rightarrow 2 \mathrm{R}-\mathrm{COOH}+\mathrm{MeS} \downarrow .
\end{aligned}
$$

However, the sorption capacity of cation-exchange resins in salt forms is much lower than that of anion-exchangers under similar conditions. The formation of sediment in the ion-exchanger phase causes the blocking of active groups, sharply reducing the kinetic cha- 
racteristics of the process, as well as complicating regeneration.

Non-woven materials based on anionite or polyampholyte fibers and $\mathrm{Fe}$ (III)-EDTA or $\mathrm{Mn}$ (III)-EDTA complexes capture $\mathrm{H}_{2} \mathrm{~S}$ [13, 17, 67-69]. Hydrogen sulfide absorbed by the liquid phase exists in the molecular and ionic forms, and during catalytic oxidation, changes into elemental sulfur:

[RR'R"R"'N]OH+ $\mathrm{H}_{2} \mathrm{~S} \rightarrow$

$$
\left[\mathrm{RR}^{\prime} \mathrm{R}^{2} \mathrm{R}^{\prime \prime} \mathrm{N}\right]^{+}+\mathrm{HS}^{-}+\mathrm{H}_{2} \mathrm{O}
$$

$2[\mathrm{Fe}(\mathrm{EDTA})]^{-}+\mathrm{H}_{2} \mathrm{~S} \rightarrow \mathrm{S}+2 \mathrm{H}^{+}+$

$$
+2[\mathrm{Fe}(\mathrm{EDTA})]^{2-} \text {, }
$$

$[\mathrm{Fe}(\mathrm{EDTA})]^{-}+\mathrm{HS}^{-} \rightarrow \mathrm{S}+\mathrm{H}^{+}+[\mathrm{Fe}(\mathrm{EDTA})]^{2-}$.

In parallel, the oxidative regeneration of the catalyst takes place:

$$
\begin{aligned}
{[\mathrm{Fe}(\mathrm{EDTA})]^{2-} } & +\mathrm{O}_{2}+2 \mathrm{H}_{2} \mathrm{O} \rightarrow \\
& \rightarrow[\mathrm{Fe}(\mathrm{EDTA})]^{-}+4 \mathrm{OH}^{-} .
\end{aligned}
$$

SORPTION OF PHENOLS. Phenol is well absorbed from gas mixtures by the hydroxyl form of strongly basic anion-exchangers [30, 40]. The sorption of phenols on ion-exchangers is inverted. Desorption is carried out by raising the temperature or treatment with organic solvents.

$$
\begin{aligned}
{\left[\mathrm{RR}^{\prime} \mathrm{R} " \mathrm{R}\right. \text { "' }} & \mathrm{N}] \mathrm{OH}+\mathrm{C}_{6} \mathrm{H}_{5} \mathrm{OH} \rightarrow \\
& \rightarrow\left[\mathrm{RR}^{\prime} \mathrm{R}^{\prime \prime} \mathrm{R}^{\prime \prime} \mathrm{N}\right]\left(\mathrm{OC}_{6} \mathrm{H}_{5}\right)+\mathrm{H}_{2} \mathrm{O}
\end{aligned}
$$

SORPTION OF HALOGENS. The absorption of molecular chlorine by strongly and weakly basic anion-exchangers proceeds through the successive stage of its dissolution and disproportionation in water of swelling of IFM $[7,9,13,16,41]$ :

$$
\begin{gathered}
\mathrm{Cl}_{2}+\mathrm{H}_{2} \mathrm{O} \rightarrow \mathrm{HCl}+\mathrm{HOCl}, \\
3 \mathrm{HOCl} \rightarrow 2 \mathrm{HCl}+\mathrm{HClO}_{3},
\end{gathered}
$$

and then through the sorption of hydrochloric and hypochlorous acids by substitution reactions on the amino groups of the ion-exchanger.

$$
\begin{aligned}
& {\left[\mathrm{RR}^{\prime} \mathrm{R}^{\prime \prime} \mathrm{R}^{\prime \prime} \mathrm{N}\right]_{2} \mathrm{CO}_{3}+2 \mathrm{HCl} \stackrel{\mathrm{nH}_{2} \mathrm{O}}{\longrightarrow}} \\
& \stackrel{\mathrm{nH}_{2} \mathrm{O}}{\longrightarrow} 2\left[\mathrm{RR}^{\prime} \mathrm{R} " \mathrm{R} \text { "'N } \mathrm{Cl}+\mathrm{H}_{2} \mathrm{O}+\mathrm{CO}_{2}\right.
\end{aligned}
$$

$\left[\mathrm{RR}^{\prime} \mathrm{R} " \mathrm{R} " \mathrm{~N}_{2}\right]_{2} \mathrm{CO}_{3}+2 \mathrm{HClO}_{3} \stackrel{\mathrm{nH}_{2} \mathrm{O}}{\longrightarrow}$ $\stackrel{\mathrm{nH}_{2} \mathrm{O}}{\longrightarrow} 2\left[\mathrm{RR}^{\prime} \mathrm{R} " \mathrm{R}\right.$ "'N] $\left(\mathrm{ClO}_{3}\right)+\mathrm{H}_{2} \mathrm{O}+\mathrm{CO}_{2}$

When halogens (chlorine, bromine and iodine) are absorbed by strongly basic anion-exchangers, a high specific capacity is also achieved by the direct use of the halide forms of the anion-exchanger of the same name. Sorption occurs due to the binding of halogens by all elements of the structure of the ion-exchanger: counterions, amino groups and the hydrocarbon matrix. With halide counterions, a complex polyhalide anion with a coordination number $\mathrm{n}$ of up to 4 is formed.

$\left[\mathrm{RR}^{\prime} \mathrm{R}^{\prime} \mathrm{R}\right.$ '”N]I $+n \mathrm{Br}_{2} \rightarrow$

$$
\rightarrow\left[\mathrm{RR}^{\prime} \mathrm{R}^{\prime} \mathrm{R} " \mathrm{~N}\right]\left[\mathrm{I}\left(\mathrm{Br}_{2}\right)_{n}\right] .
$$

The formation of polyhalide complexes of the type $\left[\mathrm{Cl}\left(\mathrm{I}_{2}\right)_{\mathrm{n}}\right]^{-},\left[\mathrm{Cl}\left(\mathrm{Br}_{2}\right)_{\mathrm{n}}\right]^{-},\left[\mathrm{Br}\left(\mathrm{I}_{2}\right)_{\mathrm{n}}\right]^{-}$, etc. is also possible

SORPTION OF PHOSGENE. Upon interaction with the hydroxyl form of the anion-exchange resin, phosgene is absorbed as anhydride of hydrochloric and carbonic acids [40]:

$$
\begin{aligned}
& 4\left[\mathrm{RR}^{\prime} \mathrm{R} \text { "R'”N }\right] \mathrm{OH}+\mathrm{COCl}_{2} \rightarrow \\
& \rightarrow 2 \text { [RR'R"R"'N]Cl + } \\
& +[\text { RR'R"R"' }]_{2} \mathrm{CO}_{3}+2 \mathrm{H}_{2} \mathrm{O}
\end{aligned}
$$

Presumably, the process proceeds in several stages: hydrolysis of sorbate (55); absorption of the formed acids by $\mathrm{OH}$ anion-exchanger (56), (57) and decomposition of its carbonate form $(58,1.59)$ : 


$$
\mathrm{COCl}_{2}+2 \mathrm{H}_{2} \mathrm{O} \rightarrow 2 \mathrm{HCl}+\mathrm{H}_{2} \mathrm{CO}_{3},
$$

2RR'R"R"'N+OH- $+2 \mathrm{HCl} \rightarrow$

$$
\rightarrow 2 \text { RR'R"R'"NCl }+2 \mathrm{H}_{2} \mathrm{O} \text {, }
$$

2RR'R"R"'N+OH'+ $\mathrm{H}_{2} \mathrm{CO}_{3} \rightarrow$

$$
\rightarrow\left(\mathrm{RR}^{\prime} \mathrm{R}^{2} \mathrm{R} " \mathrm{~N}_{2}\right)_{2} \mathrm{CO}_{3}+2 \mathrm{H}_{2} \mathrm{O} \text {, }
$$

$\left(\mathrm{RR}^{\prime} \mathrm{R} " \mathrm{R} " \mathrm{~N}\right)_{2} \mathrm{CO}_{3}+\mathrm{HCl} \rightarrow$

$\rightarrow$ RR'R"R"'NCl + RR'R"R"'NHCO

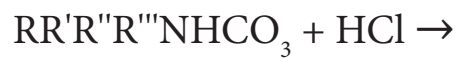

$$
\rightarrow \text { RR'R"R'"NCl }+\mathrm{H}_{2} \mathrm{O}+\mathrm{CO}_{2} \text {. }
$$

CHEMISORPTION OF NEUTRAL GASEOUS SUBSTANCES

SORPTION OF MERCAPTANS. Strongly basic anion-exchange resins in the $\mathrm{OH}$ form absorb mercaptans from various gas streams relatively well. For example, the sorption of thiophenol on a strongly basic anion-exchange resin follows the equation $[30,40]$ :

[RR'R"R"'N]OH + $\mathrm{C}_{6} \mathrm{H}_{5} \mathrm{SH} \rightarrow$

$$
\rightarrow\left[\mathrm{RR}^{\prime} \mathrm{R}^{\prime \prime} \mathrm{R} " \mathrm{~N}^{\circ} \mathrm{N}\right]\left(\mathrm{SH}_{5} \mathrm{C}_{6}\right)+\mathrm{H}_{2} \mathrm{O} \text {. }
$$

The catalytic decomposition of perchloromethylmercaptan takes place during it absorbtion:

$$
\begin{aligned}
& 4\left[\mathrm{RR}^{\prime} \mathrm{R}^{\prime} \mathrm{R}{ }^{\prime \prime} \mathrm{N}\right] \mathrm{OH}+\mathrm{CCl}_{3} \mathrm{SCl} \rightarrow \\
& \quad \rightarrow 4\left[\mathrm{RR}^{\prime} \mathrm{R} \text { "R"'N }\right] \mathrm{Cl}+\mathrm{S}+2 \mathrm{H}_{2} \mathrm{O}+\mathrm{CO}_{2} .
\end{aligned}
$$

From gaseous hydrocarbon streams, mercaptans can be removed by molecular sorption on strongly basic anion-exchangers, from which the sorbed mercaptans are easily eluted with an excess of dilute alkali solution. On cation-exchange resins in the form of heavy metal ions (copper, silver) mercaptans are sorbed with the formation of mercaptides and easily eluted with alkali solutions.

SORPTION OF CARBON DISULFIDE. The absorption of carbon disulfide by anion-exchangers is based on its ability to exhibit the properties of thioanhydride and to easily react with bases. The products of this interaction are xanthates of different types [40,70]:

$$
\begin{aligned}
& \mathrm{RNH}_{2}+\mathrm{CS}_{2} \rightarrow \mathrm{RNH}-\mathrm{CS}_{2} \mathrm{H}, \\
& \mathrm{RR}^{\prime} \mathrm{NH}+\mathrm{CS}_{2} \rightarrow \mathrm{RR}^{\prime} \mathrm{N}-\mathrm{CS}_{2} \mathrm{H} .
\end{aligned}
$$

The sorption effect does not depend on the basicity of the anion, but increases with increasing carbon disulfide concentration and temperature (by approximately $50 \%$ at $40{ }^{\circ} \mathrm{C}$ ). The obtained xanthates are unstable compounds and decompose easily under the action of acid and at elevated temperatures. Anion-exchangers in the hydrosulfide form are able to absorb carbon disulfide with the formation of trithiocarbonate by the reaction:

$$
\begin{aligned}
{\left[\mathrm{RR}^{\prime} \mathrm{R}^{\prime} \mathrm{R}{ }^{\prime \prime} \mathrm{N}\right](\mathrm{HS}) } & +\mathrm{CS}_{2} \rightarrow \\
& \rightarrow\left[\mathrm{RR}^{\prime} \mathrm{R}^{\prime \prime} \mathrm{R} " \mathrm{~N}\right]\left(\mathrm{HCS}_{3}\right) .
\end{aligned}
$$

SORPTION OF OZONE. The high oxidizing properties of ozone allow it to be efficiently decomposed on anion-exchangers in the form of the corresponding reducing ions. The possibility of formation of undesirable toxic volatile products under the action of ozone must be taken into account when choosing ion-exchangers and their ionic forms for the decomposition of $\mathrm{O}_{3}$. In principle, ozone can decompose on anion-exchangers in the form of any reducing ions. For example, anion-exchange resins in iodide form quantitatively decompose $\mathrm{O}_{3}$ with the release of an equimolar amount of free iodine, firmly held by the ion-exchanger phase $[13,40]$ :

$$
\begin{aligned}
2\left[R^{\prime} R^{\prime \prime} R^{\prime \prime}\right. & \mathrm{N}] \mathrm{I}+\mathrm{O}_{3}+\mathrm{H}_{2} \mathrm{O} \rightarrow \\
& \rightarrow\left(\left[\mathrm{RR}^{\prime} \mathrm{R}^{\prime \prime} \mathrm{R}^{\prime \prime} \mathrm{N}\right] \mathrm{OH}\right)_{2} \mathrm{I}_{2}+\mathrm{O}_{2} .
\end{aligned}
$$

The reaction occurs with the absorption of water, which slightly complicates the deozonation of dry or slightly wet gas streams. The most effective is the process of deozonation 
using the hydrazinium form of strongly acid cation-exchangers, decomposing $\mathrm{O}_{3}$ with the formation of non-toxic products [13]:

$$
\begin{aligned}
{\left[\mathrm{R}-\mathrm{SO}_{3}\right] } & \left(\mathrm{N}_{2} \mathrm{H}_{5}\right)+2 \mathrm{O}_{3} \rightarrow \\
& \rightarrow \mathrm{R}-\mathrm{SO}_{3} \mathrm{H}+2 \mathrm{H}_{2} \mathrm{O}+\mathrm{N}_{2}+2 \mathrm{O}_{2} .
\end{aligned}
$$

The release of water has a positive effect when there is a lack of moisture in the system. It is four times more effective than anion-exchangers in iodide form in terms of deozoning ability per one equivalent of the exchange capacity of cation-exchanger in hydrazine form. Compared with the latter, a number of other ionic forms are more effective (for example [RR'R"R'"N]HS, [RR'R"R"'N]HSO, [RR'R"R"'N] $\mathrm{S}_{2} \mathrm{O}_{3}$, [RR'R"R"'N] $\mathrm{HC}_{2} \mathrm{O}_{4}$ ) [40].

SORPTION OF MERCURY. The reducing property of mercury is used to absorb its vapors or aerosols on the ionites in the form of the corresponding oxidizing ions [13, 40, 71]. For example, iodinated strongly basic anion-exchangers (their halide forms saturated with free iodine) absorb from 10 to $40 \%$ of the initial mass of the chemisorbat as mercury, depending on its iodine content:

$$
\begin{aligned}
2\left[\mathrm{RR}^{\prime} \mathrm{R}^{\prime} \mathrm{R}^{\prime \prime} \mathrm{N}\right]^{+}\left[\mathrm{I}\left(\mathrm{I}_{2}\right)_{\mathrm{n}}\right]^{-}+n \mathrm{Hg} \rightarrow & \rightarrow \\
& \rightarrow\left[\mathrm{RR}^{\prime} \mathrm{R}^{\prime \prime} \mathrm{R}{ }^{\prime \prime} \mathrm{N}\right] \mathrm{I}+\left(\mathrm{HgI}_{2}\right)_{n} \downarrow .
\end{aligned}
$$

The formed precipitate of $\mathrm{HgI}_{2}$, is very firmly held in the anion-exchanger phase. Due to the sharp color contrast and the linearcolor dependence of the original anionexchanger and its spent zone, this reaction is successfully used for the building of calibration curve in determination of mercury in air. To absorb vapors and aerosols of mercury disproportionation reaction on strongly acid cation-exchange resins in the form of mercury(I) can be used:

$$
\left[\mathrm{R}-\mathrm{SO}_{3}\right]_{2} \mathrm{Hg}+\mathrm{Hg} \rightarrow 2\left[\mathrm{R}-\mathrm{SO}_{3}\right] \mathrm{Hg} .
$$

Mercury vapors and aerosols can be absorbed on strongly by acid cation-exchangers in silver form. The fine-grained metallic silver formed in the ion-exchanger phase additionally absorbs a significant amount of mercury due to the formation of amalgams, and the cation-exchanger acquires a characteristic mirror luster. The process occurs by the reactions:

$$
\begin{gathered}
2\left[\mathrm{R}-\mathrm{SO}_{3}\right] \mathrm{Ag}+\mathrm{Hg} \rightarrow\left[\mathrm{R}-\mathrm{SO}_{3}\right]_{2} \mathrm{Hg}+2 \mathrm{Ag}, \\
n \mathrm{Ag}+m \mathrm{Hg} \rightarrow \mathrm{Ag}_{n} \mathrm{Hg}_{m} .
\end{gathered}
$$

Vaporous of mercury can be removed from flue gases or air by chelation with ion-exchange fibers dispersed with $\mathrm{MnO}_{2}$ nanoparticles [17]. The removal process involves the oxidation $\mathrm{Hg}^{0} \rightarrow \mathrm{Hg}^{2+}$ followed by selective binding on fibers containing iminodiacetate functional groups, according to the reactions:

$$
\begin{aligned}
& \mathrm{Hg}^{0}+\mathrm{MnO}_{2}+4 \mathrm{H}^{+} \rightarrow \\
& \rightarrow \mathrm{Hg}^{2+}+\mathrm{Mn}^{2+}+2 \mathrm{H}_{2} \mathrm{O} \\
& 4\left[\mathrm{R}-\mathrm{NCH}_{2} \mathrm{COO}\right] \mathrm{Na}+\mathrm{Hg}^{2+}+\mathrm{Mn}^{2+} \rightarrow \\
& \rightarrow\left[\mathrm{R}-\mathrm{NCH}_{2} \mathrm{COO}\right]_{2} \mathrm{Hg}+ \\
& \quad\left[\mathrm{R}-\mathrm{NCH}_{2} \mathrm{COO}\right]_{2} \mathrm{Mn}+4 \mathrm{Na}^{+}
\end{aligned}
$$

CHEMISORPTION OF GASEOUS SUBSTANCES OF BASIC NATURE. Of the gaseous substances of alkali nature, are absorbed by IFMs, of great practical interest is ammonia and other nitrogen-containing bases (aliphatic and aromatic amines), as well as aerosols of caustic alkalis. To absorb them, one can use neutralization reactions on $\mathrm{H}$-cation exchange resins, complexation on cation-exchange resins in metal forms, as well as exchange (substitution) reactions on weakly basic anion exchange resins in salt form. 
SORPTION OF AMMONIA. For the absorption of ammonia, one can use the $\mathrm{H}$-form and some metal forms of strongly acid and weakly acid cation-exchangers, as well as salt forms of weakly basic anion-exchangers. The absorption efficiency depends on the presence of moisture in the ionite or gas. In dry cation-exchanger, the direct addition of ammonia by hydrogen forms of strongly acid and weakly acid cation-exchangers by reactions $[9,13,72,73]$ :

$$
\begin{aligned}
\mathrm{R}-\mathrm{SO}_{3} \mathrm{H}+\mathrm{NH}_{3} & \rightarrow\left[\mathrm{R}-\mathrm{SO}_{3}\right] \mathrm{NH}_{4}, \\
\mathrm{R}-\mathrm{COOH}+\mathrm{NH}_{3} & \rightarrow[\mathrm{R}-\mathrm{COO}] \mathrm{NH}_{4} .
\end{aligned}
$$

is extremely complicated. When sorbing ammonia by fibrous sulfonic cation-exchanger, the decrease in sorption occurs at the relative humidity $P / P_{\mathrm{s}}<0.07$; within $P / P_{\mathrm{s}}=0.07-1.0$, the moisture content has practically no effect on the equilibrium state or the interaction kinetics [73]. We found something similar in the capture of $\mathrm{NH}_{3}$ by IFCs based on complex compounds of $3 \mathrm{~d}$ metals $[74,75]$. That is, water is necessary not only to improve the kinetic characteristics of the process, but also is one of the components involved in the reaction that proceeds by the ionic mechanism:

$$
\begin{aligned}
& \mathrm{NH}_{3}+\mathrm{H}_{2} \mathrm{O} \underset{\leftarrow}{\stackrel{N_{H}}{ } \mathrm{OH}} \stackrel{\mathrm{NH}_{4}^{+}}{\rightarrow} \mathrm{OH}^{-}, \\
& {\left[\mathrm{R}-\mathrm{SO}_{3}\right] \mathrm{H}+\mathrm{NH}_{4}^{+}+\mathrm{OH}^{-} \stackrel{\rightleftarrows}{\leftarrow}} \\
& \left.\stackrel{\mathrm{K}}{\leftarrow}-\mathrm{SO}_{3}\right] \mathrm{NH}_{4}+\mathrm{H}_{2} \mathrm{O}, \\
& \mathrm{R}-\mathrm{COOH}+\mathrm{NH}_{4}^{+}+\mathrm{OH}^{-} \stackrel{\leftarrow}{\leftarrow} \\
& \stackrel{\mathrm{R}}{\leftarrow} \mathrm{R}-\mathrm{COO}] \mathrm{NH}_{4}+\mathrm{H}_{2} \mathrm{O} .
\end{aligned}
$$

The absorption efficiency of $\mathrm{NH}_{3}$ can be significantly increased by using cation-exchange resins in the form of salts of $3 \mathrm{~d}$ metals $\left(\mathrm{Cu}^{2+}\right.$, $\left.\mathrm{Co}^{2+}, \mathrm{Cd}^{2+}, \mathrm{Zn}^{2+}, \mathrm{Ni}^{2+}\right)$, which are complexing agents for ammonia $[13,40]$.

$$
\begin{aligned}
{[\mathrm{R}-\mathrm{COO}]_{2} \mathrm{Co}+} & n \mathrm{NH}_{3} \rightarrow \\
\rightarrow & {[\mathrm{R}-\mathrm{COO}]_{2}\left[\mathrm{Co}\left(\mathrm{NH}_{3}\right)_{n}\right] } \\
{\left[\mathrm{R}-\mathrm{SO}_{3}\right]_{2} \mathrm{Cu}+} & n \mathrm{NH}_{3} \rightarrow \\
\rightarrow & {\left[\mathrm{R}-\mathrm{SO}_{3}\right]_{2}\left[\mathrm{Cu}\left(\mathrm{NH}_{3}\right)_{n}\right] }
\end{aligned}
$$

where $n=1-4$. The sorption of ammonia by various ionic forms of sulfonic cation-exchanger increases in this order: $\mathrm{Na}^{+}<\mathrm{H}^{+}<\mathrm{Zn}^{2+}<$ $\mathrm{Cu}^{2+}<\mathrm{Co}^{2+}[13]$.

The absorption of ammonia by salt forms of anion-exchangers is also possible, for example, the interaction of ammonia with the sulfate form of the strongly basic anion-exchange resin follows the equation:

$$
\begin{aligned}
& {\left[\mathrm{RR}^{\prime} \mathrm{R}^{\prime \prime} \mathrm{R} " \mathrm{~N}\right]_{2} \mathrm{SO}_{4}+2 \mathrm{NH}_{3}+2 \mathrm{H}_{2} \mathrm{O} \rightarrow} \\
& \quad \rightarrow 2\left[\mathrm{RR}^{\prime} \mathrm{R}^{\prime \prime} \mathrm{R} \text { "'N }\right] \mathrm{OH}+\left(\mathrm{NH}_{4}\right)_{2} \mathrm{SO}_{4} .
\end{aligned}
$$

The reaction also requires water in the ionite or gas stream.

SORPTION OF AMINES. The processes of interaction of aliphatic and aromatic amines with cation-exchangers [76-78] due to their chemical similarity to ammonia are similar to those described above. For example, on strongly acid cation-exchangers the chemisorption of aliphatic and aromatic amines is carried out by fixing them on exchange centers by the reaction:

$$
\begin{aligned}
& \mathrm{R}-\mathrm{SO}_{3} \mathrm{H}+\mathrm{R}^{\prime} \mathrm{R}^{\prime \prime} \mathrm{R} \text { 'N } \rightarrow \\
& \left.\rightarrow \text { [R-SO }{ }_{3}\right]\left[\mathrm{R}^{\prime} \mathrm{R}^{\prime} \mathrm{R} " \mathrm{NH}\right] .
\end{aligned}
$$

where R' is a hydrocarbon radical; R" and R"' are $\mathrm{H}$ or a hydrocarbon radical. In the case of $\mathrm{C}_{2} \mathrm{H}_{5} \mathrm{NH}_{2}$ and $\left(\mathrm{C}_{2} \mathrm{H}_{5}\right)_{2} \mathrm{NH}$, in contrast to $\left(\mathrm{C}_{2} \mathrm{H}_{5}\right)_{3} \mathrm{~N}$, the protective properties of strongly acidic fibrous cation-exchanger do not depend on the moisture content [76]. The sorption of $\left(\mathrm{C}_{2} \mathrm{H}_{5}\right)_{2} \mathrm{NH}$ and $\left(\mathrm{C}_{2} \mathrm{H}_{5}\right)_{3} \mathrm{~N}$ from the GAM with carboxylic fibrous cation-exchanger depends on humidity, which is due to kinetic 
and diffusion barriers to the interaction of incompletely swollen cation-exchanger with amines [76]. Strong acid and weak acid cations in the form of salts of $\mathrm{d}$ metals $\left(\mathrm{Cu}^{2+}, \mathrm{Co}^{2}\right.$, $\mathrm{Cd}^{2+}, \mathrm{Ni}^{2+}$ ) can be used for the chemisorption of amines [40].

The process, as in the absorption of ammonia, is a complexation reaction, in which amine plays the role of a ligand:

$$
\begin{aligned}
{\left[\mathrm{R}-\mathrm{SO}_{3}\right]_{2}-\mathrm{Me} } & +n \mathrm{R}^{\prime} \mathrm{NH}_{2} \rightarrow \\
& \rightarrow\left[\mathrm{R}^{-\mathrm{SO}_{3}}\right]_{2}-\mathrm{Me}\left(\mathrm{R}^{\prime} \mathrm{NH}_{2}\right)_{n^{\prime}} \\
{[\mathrm{R}-\mathrm{COO}]_{2}-\mathrm{Me} } & +n \mathrm{R}^{\prime} \mathrm{NH}_{2} \rightarrow \\
& \rightarrow[\mathrm{R}-\mathrm{COO}]_{2}-\mathrm{Me}\left(\mathrm{R}^{\prime} \mathrm{NH}_{2}\right)_{n} .
\end{aligned}
$$

SORPTION OF HYDRAZINE. Among nitrogen hydrogens, hydrazine and its symmetric or asymmetric alkyl- and aryl-substituted derivatives occupy a special place in the absorption with ion-exchange chemisorbents. The tendency to complex formation and the properties of weak bases, peculiarly in aqueous solutions, allows chemisorption of these compounds from the gas phase, like amines, on metal forms of cation-exchangers and salt forms weakly basic anion-exchangers. The easy oxidation of hydrazine is the basis for the decomposition of its vapors on anion-exchange resins containing free iodine. The process is reduced to the oxidation of hydrazine by iodine [40]:

$$
2 \mathrm{I}_{2}+\mathrm{N}_{2} \mathrm{H}_{4} \rightarrow 4 \mathrm{HI}+\mathrm{N}_{2} .
$$

CONCLUSIONS. Non-woven ion-exchange fibrous materials, having several advantages over granular adsorbents, are widely used to equip gas cleaning equipment for removing toxic gases and vapors. The literature describes the chemisorption of fibrous ion-exchangers $\mathrm{SO}_{2}$, $\mathrm{NO}_{\mathrm{x}}, \mathrm{HCl}, \mathrm{HF}, \mathrm{SiF}_{4}, \mathrm{NH}_{3}$, and $\mathrm{NR}_{\mathrm{n}} \mathrm{H}_{3-\mathrm{n}}\left(\mathrm{R}^{\prime}-\right.$
$\mathrm{C}_{2} \mathrm{H}_{5} ; \mathrm{n}=1 \div 3$ ), which allows the a priori choice of IFMs in the capture of these toxicants.

The chemisorption of gases, vapors, and aerosols of acidic nature is carried out by reactions of neutralization of hydroxyl or carbonate form of strongly basic anion-exchangers or formation of "ammonium" salts with primary, secondary, or tertiary amino groups of weakly basic IFMs. Low-acid cation-exchangers in salt form could be used for absorbing acid gases. Chemisorption of gaseous ammonia, aliphatic and aromatic amines, as well as aerosols of caustic alkalis, occurs on cation-exchangers in $\mathrm{H}$ - and metal forms, as well as anion-exchangers in salt form. The peculiarity of chemisorption of gaseous substances with acidic and alkaline properties by fibrous IFMs is the neediness of water to improve the kinetic characteristics of processes, and water direct participation in the reactions that occur by the ionic mechanism.

ACKNOWLEDGMENTS. The study was done within the state budget theme "Theoretical principles of creating highly efficient sorption-filtering materials and respirators based on them", the state registration number: 0119 U002103. 
НЕТКАН ОНООБМПНН ВОЛОКНИСТІ МАТЕРІАЛИ В САНІТАРНОМУ ОЧИЩЕННН ПОВІТРЯ

А. А.-А. Еннан ${ }^{1}$ Р. М. Длубовський P. C. Хома $^{1,2^{*}}$

${ }^{1}$ Фізико-хімічний інститут захисту навколишнього середовища і людини МОН України та НАН України, вул. Преображенська, 3 , Odeca 65082;

${ }^{2}$ Одеський національний університет імені I. I. Мечникова, вул. Дворянська, 2, Одеса 65082

*e-mail: rek@onu.edu.ua

Огляд присвячено аналізу особливостей функціонування нетканих сорбційно-фільтруючих матеріалів (НСФМ), які широко використовують для спорядження газоочищувального устаткування, зокрема респіраторів - засобів індивідуального захисту органів дихання від токсичних газота пароподібних речовин. Проаналізовано використання НСФМ, зокрема іонообмінних волокнистих матеріалів (IBM), особливості їхнього отримання та будови; наведено дані щодо виробників таких матеріалів. Велику увагу приділено механізмам процесів хемосорбції при використанні IBM та ролі води в їхньому успішному здійсненні. На конкретних прикладах, що являють найбільший інтерес для практики, розглянуто окремі варіанти і деякі закономірності взаємодії волокнистих аніонітів, катіонітів та поліамфолітів за рахунок реакцій обміну, нейтралізації, окислення - відновлення, комплексоутворення і осадження з газота пароподібними речовинами. Детально описано хемосорбцію іоногенними гру- пами IBM токсикантів кислотної (оксидів сірки (IV), вуглецю (IV), азоту (IV), тетрафториду кремнію, хлористого водню, фтористого водню, тетрафториду кремнію, синильної кислоти, сірководню, фенолів, галогенів, фосгену), основної (аміаку, різноманітних амінів та гідразинів) природи, а також нейтральних сполук (меркаптанів, сірковуглецю, озону та ртуті).

Поглинання газів, випарів та аерозолів кислотного характеру здійснюється за реакціями нейтралізації гідроксильної або карбонатної форми сильноосновних аніонітів або утворення «амонійових» солей 3 первинними, вторинними або третинними аміногрупами слабкоосновних IBM. Крім сильноосновних і слабкоосновних аніонітів для поглинання кислих газів можна використовувати слабкокислотні катіоніти у сольовій формі. Хемосорбція газоподібних аміаку, аліфатичних та ароматичних амінів, а також аерозолів їдких лугів відбувається на катіонітах в Н- та метал-формах, а також аніонітах в сольовій формі.

Ключові слова: іонообмінні волокна, хемосорбція, токсичні гази та пари.

\section{REFERENCES}

1. Kurylenko O.D., Ennan A.A., Nekrjach Je.F., Blinder V.I. Ionoobminni voloknysti materialy na osnovi celjulozy v gazoochystci. Visnyk AN URSR. 1975. 39(7): 37-45. (In Ukrainian).

2. Zverev M.P. Chemisorption fibers. Moscow, Khimia, 1981. 191 p. (In Russian)

3. Ennan A.A. Fiziko-himicheskie osnovy ulavlivanija, nejtralizacii i utilizacii sva- 
rochnyh ajerozolej. Book of $1^{\text {st }}$ International Science-Practical Conference "Protection of Environment, Health, and Safety in Welding", Odessa, Astroprint, 2002. P. 10-37. (In Russian).

4. Ennan A.A., Asaulova T.A. Razrabotka, proizvodstvo i vnedrenie ionoobmennyh voloknistyh materialov na osnove cellljulozy i polikaproamida. Book of $1^{\text {st }}$ International Science-Practical Conference "Protection of Environment, Health, and Safety in Welding", Odessa, Astroprint, 2002. P. 286-295. (In Russian).

5. Zverev M.P., Zakharov S.V. Hemosorbcionnye volokna - materialy dlja zashhity sredy obitanija ot vrednyh vybrosov. Book of $1^{\text {st }}$ International Science-Practical Conference "Protection of Environment, Health, and Safety in Welding", Odessa, Astroprint, 2002. P. 296-304. (In Russian).

6. Economy J., Dominguez L., Mangun C.L. Polymeric Ion-Exchange Fibers. Ind. Eng. Chem. Res. 2002; 41: 6436-6442. doi: 10.1021/ie0204641

7. Zverev M.P. Fibre Chemisorbents - Material for Environmental Protection. A Review. Fibre Chemistry. 2002; 34: 456-465. doi: 10.1023/A:1022972511231

8. Baidenko V.I., Ennan A.A., Zakharenko Yu.S. Razrabotka i primenenie voloknistyh hemosorbentov $\mathrm{v}$ praktike individual'noj protivogazovoj zashhity. Visn. Odes. nac. univ., Him. 2003; 8(7): 24-39. (In Russian).

9. Ennan A.A., Baidenko V.I. Sorbcionno fil'trujushhie voloknistye ionity dlja individual'noj protivogazovoj zashhity (Obzor). Ekotehnologii i resursosberezhenie. 2004; (5): 43-54. (In Russian).

10. Druzhinina T.V., Kobrakov K.I., Abaldu- eva E.V., Zhigalov I.B. Chemisorption Fibers for Sorption of Metal ions and Acid Gases. Bezopasnost Zhiznedeyatelnosti. 2004; (11): 31-34. (In Russian).

11. Kim Y.-S., Hwang T.-S., Lee H.-K., Park J.-W., Kim S.-M. Removal of Toxic Gases on Strong/and Weak-Base Anion Exchange Fibers. J. Ind. Eng. Chem. 2004; 10(4): 504-510.

12. Ennan A.A., Asaulova T.A., Baidenko V.I. The Production of Nonwoven Needle-Punched Sorbtion and Filtering Materials from Ion Exchange Fibrous Wastes. Jenergotehnologii $i$ resursosberezhenie. 2010; (2): 42-46. (In Russian).

13. Soldatov V.S., Kosandrovich E.H. Ion Exchangers for Air Purification. Ion Exchange and Solvent Extraction. A Series of Advances. CRC Press. 2011; 20: 45-115. doi: 10.1201/b10813-3

14. Kosandrovich E.G., Soldatov V.S. Fibrous Ion Exchangers. Ion Exchange Technology I. Theory and Materials. Springer. 2012; 22: 299-371. doi: 10.1007/978-94-007-1700-8_9

15. Rustamov M.K., Gafurova D.A., Karimov M.M., Rustamova N.M., Bekchonov D.Zh., Mukhamediev M.G. Application of ion-exchange materials with high specific surface area for solving environmental problems. Russ. J. Gen. Chem. 2014; 84(13): 25452551. doi: $10.1134 / \mathrm{s} 1070363214130106$

16. Polikarpov A.P., Shunkevich A.A., Grachek V.I., Medyak G.V. FIBAN fibrous ion exchangers: Synthesis, modification, application. Russ. J. Gen. Chem. 2017; 87(6): 1418-1427. doi: 10.1134/ S1070363217060457

17. SenGupta A.K. Ion Exchange in Environmental Processes: Fundamentals, Applications and Sustainable Technology. Wiley. 
2017. 550 p. doi: $10.1002 / 9781119421252$

18. Genis A.V., Kuznetsov A.V. Perspective Developments In The Production Of Fibrous Polymeric Sorbents. Rossijskij Himicheskij Zhurnal. 2019; 63(1): 27-45. doi: 10.6060/rcj.2019631.2 (In Russian).

19. Perepelkin K.E. Chemical Fibers with Specific Properties for Industrial Application and Personnel Protection. J. Ind. Textiles. 2001; 31(2): 87-102. doi: 10.1106/xu8hc5j5-8blt-2eao

20. Chen W. Synthesis of Polypropylene Strong Acid Cationic Exchange Fiber. Adv. Mater. Res., 2015; 1088: 434-438. doi: 10.4028/ www.scientific.net/amr.1088.434

21. Henmi M., Yoshioka T. Studies of ion-exchange fiber "IONEX" for precoating material. Desalination. 1993; 91(3): 319-332. doi: 10.1016/0011-9164(93)80068-x

22. Matsumoto H., Wakamatsu Y., Minagawa M., Tanioka A. Preparation of ion-exchange fiber fabrics by electrospray deposition. J. Colloid Interface Sci. 2006; 293(1): 143-150. doi: 10.1016/j.jcis.2005.06.022

23. Lee C.H., Kang S.K., Lim J.A., Kwark Y.-J., Lim H.S., Kim J., Cho J.H. Counterions-exchangeable, multifunctional polyelectrolyte fabrics. J. Mater. Chem. 2012; 22(29): 14656. doi: 10.1039/c2jm31718d

24. Park H.-J., Na C.-K. Preparation of anion exchanger by amination of acrylic acid grafted polypropylene nonwoven fiber and its ion-exchange property. J. Colloid Interface Sci. 2006; 301(1): 46-54. doi: 10.1016/j.jcis.2006.05.003

25. Zargaran M., Shoushtari A.M., Abdouss M. Diametric swelling and hydrophilic characteristics of fibrous acrylic ion exchanger. J. Appl. Polym. Sci. 2008; 110(6): 3843-3847. doi: 10.1002/app.28497
26. Gafurova D.A. Physico-chemical characteristic of formation, properties of anion exchangers and polycomplexones on the basis of acrylic fiber. Abstract of Doctor's degree dissertation, 02.00.04, 02.00.06. Tashkent, 2014, $70 \mathrm{p}$.

27. Toropin V.M., Kremenchutskiy G.M., Burmistrov K.S., Shunkevich O.A., Polikarpov O.P. Synthesis and antibacterial properties of 4-aminophenylsulfonamide immobilized on the polymeric carrier. Pharm. Rev. 2017; (1): 5-10. (In Ukrainian).

28. Kosandrovich E.G., Shachenkova L.N., Nesteronok P.V., Yakubel V.N., Soldatov V.S. Synthesis and Properties of the New Fibrous Anion Exchanger with Aminoethylpiperazine Functional Groups. Proc. National Acad. Sci. Belarus. Chem. Ser. 2016; 52(4): 16-23. (In Russian).

29. Kosandrovich E.G. Physical chemical processes during the sorption of gaseous acids and bases by ion exchangers. Abstract of Doctor's degree dissertation, 02.00.04. Minsk, 2020, 43 p. (In Russian).

30. IMT - Ion-exchange Materials and Technologies. Available at http://imt-filter.com

31. Kopylova V.D., Bychkovskaya G.I., Zverev O.M. Statics and kinetics of interaction of acids and alkalis with VION AN-1 fibrous pyridine-containing chemisorbent. Russ. J. Phys. Chem. A. 2008; 82(3): 410-414. doi: 10.1134/S0036024408030151

32. Medyak G.V., Shunkevich A.A., Polikarpov A.P., Pansevich V.V., Akulich Z.I. Evaluation of factors affecting the sorption of sulfur dioxide by FIBAN fibrous anion exchangers. Proc. National Acad. Sci. Belarus. Chem. Ser. 2021; 57(1): 101-108. doi: 10.29235/1561-8331-2021-57-1-101-108 (In Russian). 
33. Ennan A.A., Abramova N.N., Khoma R.E. Katalog vigotovljaemih zasobiv individual'nogo zahistu. Physical-Chemical Institute for Environment and Human Protection of MES of Ukraine and NAS of Ukraine. Ed. by A.A. Ennan. Odesa, Astroprint, 2017. 52 p. (in Ukrainian).

34. Air filters and dust eliminators. Gas Phase filtration. Available at http://airff.cz

35. Ennan A.A., Gelmboldt V.O. Silicon tetrafluoride in reactions with organic bases. Odessa, Ecology, 2005. 160 p. (In Russian)

36. Ashirov A. Ion exchange purification of wastewater, solution and gases. Leningrad, Khimiya, 1983. 295 p. (In Russian).

37. Hwang T.-S., Kim Y.-S., ParkJ.-W.,LeeH.-K. Adsorption properties of $\mathrm{SO}_{2}$ on PANbased fibrous ion exchanger and its potential for air purification. J. Ind. Eng. Chem. 2004; 10(1): 139-145.

38. Wasag H., Soldatov V., Kosandrovich E., Sobczuk H. Odour Control By Fibrous Ion Exchangers. Chem. Eng. Trans. 2008; 35(3): 293-304.

39. Arakeljan I.A. Himzashhitnyj material na osnove neuglerodnyh sorbentov dlja fil'trujushhej zashhitnoj odezhdy. Abstract of Ph.D dissertation, 05.19.01. Kazan, 2009, 20 p. (In Russian).

40. Chikin G.A., Myagkoy O.N. Ion Exchange Methods for Purification of Substances, Voronezh, Voronezh State University, 1984. 372 p. (In Russian).

41. Garipov I., Khaydarov R., Gapurova O., Khaydarov R., Evgrafova S. The Application of Fiber Ion Exchange Sorbents for Wastewater Treatment and Purification of Gas Mixtures. J. Energ. Env. Chem. Eng. 2020; 5(1): 10-13. doi: 10.11648/j. jeece. 20200501.12
42. Marinina O.N., Burkhanova R.A., Marinin N.A. Investigation into the Regularities of Hydrogen Fluoride Collection by the Developed Fibrous Ion-Exchange Material Under Dynamic and Static Conditions. IOP Conference Series: Materials Science and Engineering. 2021; 1079(5): 052081. doi: 10.1088/1757-899x/1079/5/ 052081

43. Japar S.M., Brachaczek W.W. Artifact sulfate formation from $\mathrm{SO}_{2}$ on nylon filters. Atmos. Environ. 1984; 18(11): P. 24792482. doi: 10.1016/0004-6981(84)90018-0

44. Khoma R.E. Acid-base interaction and sulfooxidation at chemosorption of sulfur dioxide by alkylamines aqueous solutions. Abstract of Doctor's degree dissertation, 02.00.01. Kyiv, 2019, 50 p. (In Ukrainian).

45. Kosandrovich E.G., Doroshkevich O.N. Fibrous amino carboxylic sorbent for air purification from sulfur dioxide. Proc. $\mathrm{Na}$ tional Acad. Sci. Belarus. Chem. Ser. 2014; 50(1): 91-95. (In Russian).

46. Ennan A.A.-A., Khoma R.E., Impregnated Fibrous Chemosorbents of Acid Gases for Respiratory Purpose. Visn. Odes. nac. univ., Him. 2017; 22(4): 53-68. doi: 10.18524/2304-0947.2017.4(64).115924 (In Ukrainian).

47. Ennan A.A.-A., Khoma R.E., Dlubovskiy R.M., Zakharenko Y.S., Abramova N.N., Mikhaylova T.V., Barbalat D.O. Effect of Modifying Additives on Chemosorption of Sulfur (IV) Oxide by Fibrous Material Impregnated with Polyethylenepolyamine. Visn. Odes. nac. univ., Him. 2020; 25(4): 56-73. doi: 10.18524/23040947.2020.4(76).216927 (In Russian).

48. Kiselev A.V. Intermolecular Interactions in Adsorption and Chromatography. 
Moscow, Vysshaya Shkola, 1986. 360 p. (In Russian).

49. Khoma R.E., Ennan A.A., Baumer V.N., Puzan A.N., Koksharova T.V., Mazepa A.V. Onium salts of sulfur-containing oxyanions resulting from reaction of sulfur(IV) oxide with aqueous solutions of 1,2-diamines and morpholine. Russ. J. Inorg. Chem. 2017; 62(6): 751-760. doi: 10.1134/ S0036023617060109

50. Kosandrovich E.G., Pushkarchuk A.L., Bezyazychnaya T.V., Soldatov V.S. Peculiarities of sulfur dioxide sorption from air by weak base anion exchangers. Proc. $\mathrm{Na}$ tional Acad. Sci. Belarus. Chem. Ser. 2020; 56(3): 263-270. doi: 10.29235/1561-83312020-56-3-263-270 (In Russian).

51. Christensen J.J., Izatt R.M., Wrathall D.P., Hansen L.D. Thermodynamics of proton ionization in dilute aqueous solution. Part XI. pK, $\Delta \mathrm{H}^{\circ}$, and $\Delta \mathrm{S}^{\circ}$ values for proton ionization from protonated amines at $25^{\circ}$. J. Chem. Soc. 1969; A0(0): 1212-1223. doi: $10.1039 / \mathrm{j} 19690001212$

52. Nielsen E., Ladefoged O., Soborg I. Evaluation of health hazards by exposure to $\mathrm{N}, \mathrm{N}$-Dimethyl-1,3-propanediamine and proposal of a health-based quality criterion for ambient air. Copenhagen. 2013. Available at https://www2.mst.dk/Udgiv/publications/2013/08/978-87-9302633-9.pdf

53. Abdulkhakova Z.Z., Sochilin V.E., Zverev M.P. Capture of nitrogen oxides with a fibre chemisorbent. Fibre Chem. 2000; 32(5): 374-376. doi: 10.1007/bf02360646

54. Asaulova T.A., Ennan A.A., Zhbankov R.G., Alimov I.F. Study of products of interaction of hydrogen fluoride with a polycaproamide-based fibrous sorbent. Zhur- nal Prikladnoi Khimii. 1989; 62(8): 18961899. (In Russian).

55. Asaulova T.A., Baidenko V.I., Ennan A.A. Hydrogen fluoride absorption under static conditions by a polycaproamide-based fibrous anion-exchange resin. Zhurnal Prikladnoi Khimii. 1991; 64(6): 13591361. (In Russian).

56. Korshunova T.A., Kosandrovich E.G., Soldatov V.S. Hydrogen Chloride Absorption FROM THE Air with the Fibrous Ion Exchangers FIBAN. Russ. J. Appl. Chem. 2010; 83(7): 1159-1169. doi: 10.1134/ s1070427210070013

57. Elinson I.S., Tsygankov V.I., Martinovich V.I., Soldatov V.S. Air purification from hydrogen fluoride by FIBAN ion-exchange fibers. Book of $1^{\text {st }}$ International Science-Practical Conference "Protection of Environment, Health, and Safety in Welding", Odessa, Astroprint, 2002. P. 377-383. (In Russian).

58. Song R., Zhang A. Study on dynamic adsorption of HF gas by ion-exchange fiber. J. Hyg. Res. 2002; 31(5): 382-384.

59. Ennan A.A., Baidenko V.I. Mechanism of silicon tetrafluoride sorption by anionites. I. Role of water. Issues of Chemistry and Chemical Technology. 2005; (6): 64-68. (In Russian).

60. Chebotarev A.N., Cachan S.V. Potentiometric titration of HF dilute aqueous solutions by nitrogen-containing organic bases. I. Monoamines. Zhurnal Fizicheskoi Khimii.1991; 65(3): 682-687. (In Russian).

61. Baidenko V.I., Ennan A.A. On mechanism of silicon tetrafluoride sorption by anionites. 2. Composition of the interaction products. Issues of Chemistry and Chemical Technology. 2005; (11): 50-53. (In Russian). 
62. Chebotaryov A.N., Rakhlickaya E.M., Khoma R.E., Kachan S.V. Potentiometric Investigation of the Acid-Basic Equilibria IN System "Hexafluorosilicic Acid - Water - Nitrogen-Containing Organic Base". Visn. Odes. nac. univ., Him. 2005; 10(8): 121-130. (In Russian).

63. Polyakov V.A., Barash A.N., Zverev M.P., Viglin V.E., Belenkov E.M., Alikberova L.Y., Kostina T.F., Sycheva N.A. Method of cleaning air from cyanic components. $\mathrm{Pa}-$ tent SU, no 1338876, 23.09.1987. (In Russian).

64. Barash A.N., Zverev M.P. Malinovskii E.K., Kalyanova N.F. Sorption of hydrogen sulfide by VION anion-exchange fibres. Fibre Chem. 1989; 20(6): 372-374. doi: 10.1007/BF00547139

65. Li Q., Lancaster J.R. Chemical foundations of hydrogen sulfide biology. Nitric Oxide, 2013; 35: 21-34. doi:10.1016/j. niox.2013.07.001

66. Voronova L.V., Gorlenko L.E., Emel'janova G.I., Zverev M.P., Lunin V.V. Method of gas scrubbing from hydrogen sulfide. Patent RU, no 2048865, 27.11.1995. (In Russian).

67. Egiazarov Yu.G., Potapova L.L., Radkevich V.Z., Soldatov V.S., Shunkevich A.A., Cherches B.Kh. New catalytic systems based on fibrous ion exchangers. Chemistry for Sustainable Development. 2001; 9(3): 417-431. (In Russian).

68. Soldatov V.S., Kashinskii A.V., Martinovich V.I. Catalytic removal of hydrogen sulfide from air using FIBAN ion-exchange fibers. Theor. Found. Chem. Eng. 2010; 44(4): 623627. doi: 10.1134/s0040579510040482

69. Wasag H. Removal of Hydrogen Sulphide from Air by Means of Fibrous Ion Exchan- gers. Int. J. Environ. Ecol. Eng. 2012; 6(4): 219-223. doi: 10.5281/zenodo.1070999

70. Grachek V.I., Shunkevich A.A., Isakovich O.I., Marstynkevich R.V., Pansevich V.V. Synthesis and properties of new N,S-containing fibrous ion exchangers. Russ. J. Appl. Chem. 2013; 86(11): 17071712. doi: 10.1134/s1070427213110128

71. Miller M.B., Dunham-Cheatham S.M., Gustin M.S., Edwards G.C. Evaluation of cation exchange membrane performance under exposure to high $\mathrm{Hg}^{0}$ and $\mathrm{HgBr}_{2}$ concentrations. Atmos. Meas. Tech. 2019; 12(2): 1207-1217. doi: 10.5194/amt-121207-2019

72. Wasag H., Pawłowski L, Soldatov V., Kosandrovich E. Removal of ammonia from air by fibrous ion exchangers. Chem. Eng. Trans. 2009; 35(3): 387-394.

73. Kosandrovich E.G. Sorption of ammonia and sulfur dioxide by fibrous ion exchangers. Abstract of Ph.D dissertation, 02.00.04. Minsk, 2005, 20 p. (In Russian).

74. Ennan A.A.-A., Khoma R.E., Dlubovskiy R.M., Gridyaev V.V., Mikhaylova T.V. Fibrous Chemisorbent of Sulfur Dioxide Based on the Complex Compounds of Cooper (II) Sulphate and Polyethylenepolyamine. Visn. Odes. nac. univ., Him. 2018; 23(2): 95-105. doi: 10.18524/23040947.2018.2(66).132053 (In Russian).

75. Ennan A.A.-A., Khoma R.E., Dlubovskiy R.M., Abramova N.N., Mikhaylova T.V. Fibrous Chemisorbent-Amfolite Based on the Complex Compounds of Nickel (II) Chloride and Ethylenediamine.. Visn. Odes. nac. univ., Him. 2019; 24(3): 90-102. doi: 10.18524/23040947.2019.3(71).177739 (In Russian).

76. Kosandrovich E.G. Sorption of ethyl- 
amines from air by fibrous ion exchangers. 1. Fiban K-1, a strong acid cation exchanger. Proc. National Acad. Sci. Belarus. Chem. Ser. 2014; 50(4): 11-15. (In Russian).

77. Doroshkevich O.N., Kosandrovich E.G., Kashinskii A.V., Shachenkova L.N., Zelenkovskii V.M. Sorption of ethylamines from air by fibrous ion exchangers. 2. FIBAN K-4, a weak acid cation exchanger. Proc. National Acad. Sci. Belarus. Chem. Ser. 2014; 50(4): 16-20. (In Russian).
78. Kosandrovich E.G., Shachenkova L.N., Pushkarchuk A.L., Bezyazychnaya T.V., Soldatov V.S. Mathematical description of ethylamine sorption from air by fibrous cation exchangers under conditions of limited sorbate permeability. Proc. National Acad. Sci. Belarus. Chem. Ser. 2020; 56(1): 7-14. doi: 10.29235/1561-8331-2020-561-7-14 (In Russian).

Стаття надійшла 08.07.2021. 